\title{
Morphological, cranial and coat colour variations in Mus musculus castaneus populations of Pothwar, Pakistan
}

Shahnaz Bibi ${ }^{1}$, Muhammad Sajid Nadeem ${ }^{1 *}$, Muhammad Mushtaq ${ }^{1}$, Amjad Rashid Kayani ${ }^{1}$, Tariq Mahmood ${ }^{2}$ and Franc Janzekovic ${ }^{3}$

1. Department of Zoology, PMAS-Arid Agriculture University Rawalpindi, Pakistan

2. Department of Wildlife Management, PMAS-Arid Agriculture University Rawalpindi, Pakistan

3. Faculty of Natural Sciences and Mathematics, University of Maribor, Koroska 160, 2000 Maribor Slovenia

*Corresponding author's email: sajidnm@uaar.edu.pk

Citation

Shahnaz Bibi, Muhammad Sajid Nadeem, Muhammad Mushtaq, Amjad Rashid Kayani, Tariq Mahmood and Franc Janzekovic. Morphological, cranial and coat colour variations in Mus musculus castaneus populations of Pothwar, Pakistan. Pure and Applied Biology. Vol. 11, Issue 1, pp271-283. http://dx.doi.org/10.19045/bspab.2022.110029

\begin{tabular}{llll}
\hline \hline Received: 30/03/2021 & Revised: 18/05/2021 & Accepted: 31/05/2021 & Online First: 15/06/2021 \\
\hline
\end{tabular}

\section{Abstract}

The species diversities of Mus musculus populations in Pakistan were not examined well till today, irrespective of its geographic importance being situating in a midpoint of the homeland of house mouse diversity. Cytochrome $\mathrm{b}$ gene analysis of $M$. musculus castaneus populations of northern Pakistan revealed that this South Asian subspecies is highly diverse genetically, harboring four known sub-lineages. Here we performed the morphological analysis of mice samples from the Pothwar Plateau, northern Pakistan which have already been genetically characterized by Cytochrome b gene analysis. Discriminant Function Analysis (DFA) of 18 morphometric, cranial and coat colour variables was applied to 140 of these genetically characterized adult specimens. Discriminant Function Analysis (DFA) showed 50-70\% morphological isolation between four sub-lineages of $M$. m. castaneus identified through molecular analyses. These results thus suggest that the house mice experienced the genetic admixing of the four castaneus sub-lineages in this plateau, perhaps reflecting the rapid growth of local human populations at some prehistorical times.

Keywords: Cytochrome b; Discriminant Function Analysis; Morphological variations; Mus musculus castaneus

\section{Introduction}

Of all the mice species within sub-genus Mus, the commensal house mouse Mus musculus is well known for its well debated evolution and radiation [1]. It has been the subject of many researchers for its wide range of genetic differentiation and history of worldwide colonization and ecological adaptation. Attempts to classify house mouse subspecies on morphological basis resulted in many ambiguities and it was only after the advent of molecular techniques and their use in taxonomy that the differentiation was made between the different species and morphological variant populations of the same species. Mus musculus is now regarded as a polytypic species represented by three closely related and morphologically similar subspecies (Mus musculus musculus, Mus musculus domesticus and Mus 
musculus castaneus) having varying degree of gene flow and sexual incompatibility which have been reported to be radiated about 0.5 million years ago [2]. Of these $M$. musculus castaneus is widespread mainly in Southeast Asia [1, 3] and is more polytypic as well as diverse genetically e.g. [4] than M. m. domesticus or M. m. musculus. The origin, genetic constitution and distribution of M. m. musculus and $M . m$. domesticus is becoming reasonably well documented and these two subspecies represent genetically well-defined homogeneous entities $[5,6]$. This is not the case for $M . m$. castaneus which is far from completely elucidated and still remains poorly documented [6]. However, these studies which investigated the genetic diversity and distribution of $M$. $m$. castaneus, didn't study the Castaneus populations of Pakistan to the extent it was studied in other areas of its distribution as very few samples from Pakistan were included, so its biogeography is still not known properly. We presented the first major effort to resolve this issue and added to the knowledge of genetic constitution, phylogeography and colonization history of $M$. $m$. castaneus in one of the most important part of its range [7]. The aim of the present study was to make an attempt to identify the genetically characterized taxa of Mus on the basis of their body measurements, skull and pelage characters and to reveal whether morphometric differentiation corresponds to molecular data.

\section{Materials and Methods}

\section{Study area and sample collection}

House mouse sampling carried out in the Pothwar Plateau of Punjab Province, Pakistan, a region bounded by the Murree hills and foothills of the Himalayas in the north, the Jhelum River in the east, the Salt range in the south, and the Indus River in the west (roughly latitudes $32^{\circ} 22^{\prime}$ to $34^{\circ} \mathrm{N}$ and longitudes $71^{\circ} 30^{\prime}$ to $73^{\circ} 30^{\prime}$ E) (Fig. 1). Seventeen localities were surveyed between May 2011 and April 2013 using a mixture of live and snap traps (Table 1). Sampling localities encompassed a range of habitats, including houses (inside or near human habitations), agricultural fields (wheat, groundnut and sweet pea), and uncultivated areas characterized by dry pebble and stone substrates, scrublands with sparse shrub cover, or open forests dominated by Acacia and Olea trees and Ziziphus shrubs.

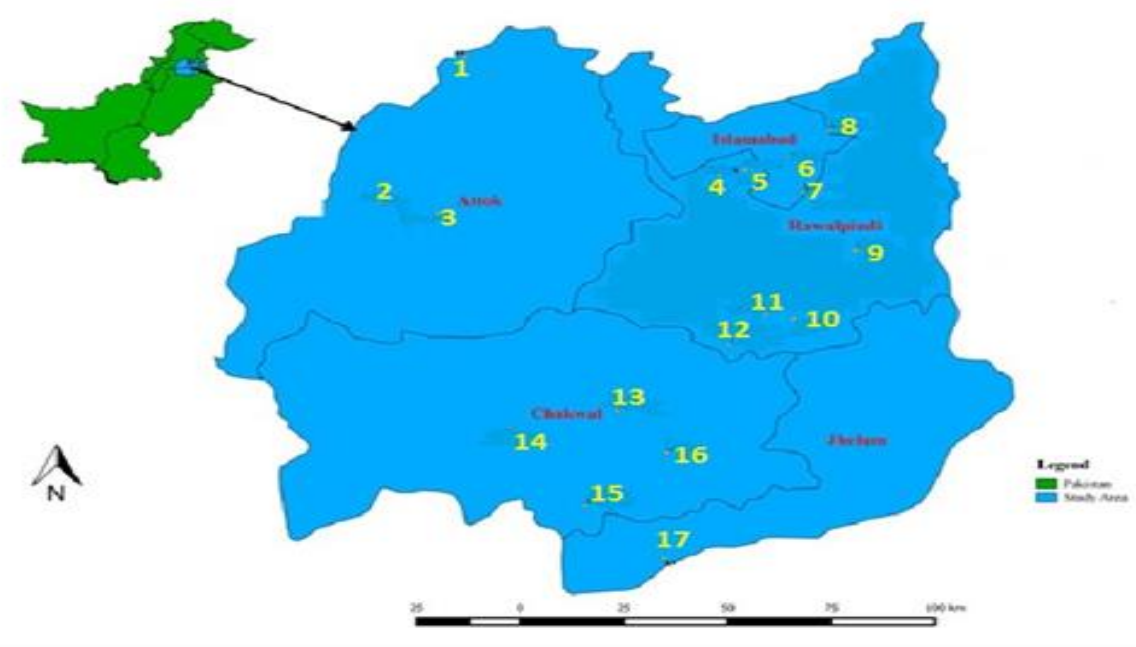

Figure 1. Map of the study area showing capturing sites(numbers) in each district of the Pothwar region 
Table 1. Collection localities, sample size and geographical coordinates of mice specimens analyzed in this study

\begin{tabular}{|c|c|c|c|c|c|c|}
\hline District & Locality/Village & $\begin{array}{c}\text { Mus } \\
\text { cookii }\end{array}$ & $\begin{array}{c}\text { Mus } \\
\text { terricolor }\end{array}$ & $\begin{array}{c}\text { Mus musculus } \\
\text { castaneus }\end{array}$ & $\begin{array}{l}\text { Latitude } \\
\text { (N) }\end{array}$ & $\begin{array}{l}\text { Longitude } \\
\text { (E) }\end{array}$ \\
\hline \multirow[t]{2}{*}{ Attock } & Rangli & --- & ---- & 12 & $33^{\circ} 29^{\prime} 37.9^{\prime \prime}$ & $72^{\circ} 06^{\prime} 9.5^{\prime \prime}$ \\
\hline & Kisran & ---- & ---- & 13 & $33^{\circ} 28^{\prime} 14.8^{\prime \prime}$ & $72^{\circ} 15^{\prime} 07.1^{\prime \prime}$ \\
\hline \multirow[t]{4}{*}{ Chakwal } & Bari & ---- & ---- & 12 & $32^{\circ} 55^{\prime} 46.1^{\prime \prime}$ & $72^{\circ} 43^{\prime} 45.8^{\prime \prime}$ \\
\hline & $\begin{array}{c}\text { Khokharzare } \\
\text { Dam }\end{array}$ & ---- & ---- & 9 & $32^{\circ} 48^{\prime} 48.6^{\prime \prime}$ & $72^{\circ} 51^{\prime} 36.7^{\prime \prime}$ \\
\hline & Mumdot & ---- & ---- & 11 & $32^{\circ} 52^{\prime} 26.6^{\prime \prime}$ & $72^{\circ} 27^{\prime} 24.2^{\prime \prime}$ \\
\hline & Makhial & --- & --- & 12 & $32^{\circ} 39^{\prime} 43.9^{\prime \prime}$ & $72^{\circ} 39^{\prime} 20.77^{\prime \prime}$ \\
\hline Jhelum & Ahmadabad & $\begin{array}{ll}--- \\
--\end{array}$ & $\begin{array}{ll}--- \\
--\end{array}$ & 12 & $32^{\circ} 31^{\prime} 11.9^{\prime \prime}$ & $72^{\circ} 51^{\prime} 42.0^{\prime \prime}$ \\
\hline \multirow[t]{6}{*}{ Rawalpindi } & Usmanzada Adra & $\begin{array}{ll}--- \\
\end{array}$ & 01 & 9 & $33^{\circ} 11^{\prime} 27.3^{\prime \prime}$ & $73^{\circ} 10^{\prime} 52.1^{\prime \prime}$ \\
\hline & Koont Farm & 01 & ---- & 10 & $33^{\circ} 06^{\prime} 58.0^{\prime \prime}$ & $73^{\circ} 00^{\prime} 52.2^{\prime \prime}$ \\
\hline & Gujar Khan & ---- & ---- & 10 & $33^{\circ} 15^{\prime} 31.15^{\prime \prime}$ & $73^{\circ} 18^{\prime} 19.1^{\prime \prime}$ \\
\hline & Kalar Syedan & ---- & ---- & 8 & $33^{\circ} 23^{\prime} 6.37^{\prime \prime}$ & $73^{\circ} 20^{\prime} 13.1^{\prime \prime}$ \\
\hline & Chakri & ---- & ---- & 7 & $33^{\circ} 35^{\prime} 22.53^{\prime \prime}$ & $72^{\circ} 58^{\prime} 42.7^{\prime \prime}$ \\
\hline & Rata amral & ---- & ---- & 7 & $33^{\circ} 36^{\prime} 20.88^{\prime \prime}$ & $73^{\circ} 2^{\prime} 37.49^{\prime \prime}$ \\
\hline \multirow[t]{4}{*}{$\begin{array}{c}\text { Islamabad } \\
\text { Capital } \\
\text { Territory }\end{array}$} & Sihala & ---- & ---- & 3 & $33^{\circ} 32^{\prime} 38.66^{\prime \prime}$ & $73^{\circ} 11^{\prime} 48.8^{\prime \prime}$ \\
\hline & Pind Bhegwal & ---- & ---- & 02 & $33^{\circ} 43^{\prime} 7.2^{\prime \prime}$ & $73^{\circ} 15^{\prime} 44.4^{\prime \prime}$ \\
\hline & Taramri & ---- & ---- & 02 & $33^{\circ} 38^{\prime} 39.13^{\prime \prime}$ & $73^{\circ} 9^{\prime} 51.69^{\prime \prime}$ \\
\hline & Mohra nur & ---- & ---- & 01 & $33^{\circ} 42^{\prime} 0^{\prime \prime}$ & $73^{\circ} 10^{\prime} 0^{\prime \prime}$ \\
\hline
\end{tabular}

\section{Morphological analysis}

All the genetically characterized specimens were subjected to morphometric, cranial and coat colour analysis. In addition to body weight (BW), four body measurements included in the morphometric analysis were head and body length (HBL), tail length (TL) from rump to the last tail vertebra, ear length (EL) from basal notch to distal tip, and hind foot length without claw (HFL) were recorded in $\mathrm{mm}$. To minimize the effect of on to genetic growth, only adult specimens were used. Apart from the external body measurements, skull measurements of the specimens were also taken using a digital caliper accurate to the nearest $0.05 \mathrm{~mm} \quad[8,9] \quad$ The cranial measurements that were included are greatest skull length (GSL), nasal length (NL) zygomatic breadth (ZB), incisive foramen length (IFL), cranial depth (CD), and cranial breadth (CB). To determine the pelage colour and texture, round skins of the specimens were prepared. Pelage colour of dorsal and ventral side of the body was determined by using Munsell colour chart [10]. Munsell colour chart uses tripartite colour scores i.e. hue, value and chroma to describe a colour. Hue depicts whether a colour looks yellow, green, red, blue or purple. Value indicates lightness of the 
colour while chroma indicates its departure from a neutral colour of the same lightness.

\section{Statistical analysis}

Discriminant function analysis (DFA) of morphometric, cranial and coat colour variables was performed in SPSS16 to predict membership of each specimen to the respective species/sub-lineage identified on the basis of molecular analysis. Discriminant score of two linear functions for each specimen was used to classify each individual.

\section{Results}

According to Cytb analysis [7] Mus fauna of Pothwar region comprises of three Mus species, namely Mus musculus castaneus (Accession numbers KY661759 to KY661856), Mus terricolor (Accession no KX790792) and Mus cookii (Accession no KX790791). Out of these species M. m. castaneus was reported to be the most abundant one and further genetic analysis concentrating on $M . m$. castaneus (CAS) proved this sub-species highly diverse and diverged into four sub-lineages named (Fig.

2) hereafter CAS-1, CAS-2, CAS-3 and CAS-4 [3].

\section{Morphological variations}

As according to genetic characterization $M$. $m$. castaneus turned out to be the most abundant species recorded from Pothwar region which was further differentiated into four sub-lineages, while all other species were represented by just one or two specimens so those species were not included in further morphological analyses. So variations in external body characters of 140 collected M. m. castaneus specimens were compared among four sub-lineages. Highest BW was recorded for CAS 2 (14.9 $\pm 2.65 \mathrm{~g})$, followed by CAS $4(14.0 \pm 3.28)$, and CAS $3(13.4 \pm 3.6)$ while lowest BW was observed in CAS-1 (11.8 \pm 4.57). In the case of HBL, trend of highest and lowest was similar as for BW with CAS 1 being smallest with $73.5 \pm 8.90$ and CAS 2 largest with 77.8 \pm 8.17. But for CAS 3 and CAS 4 trend was somewhat different with CAS 3 (76.3 +11.35$)$ larger than CAS 4 (75.5 \pm 9.02$)$. TL was measured $65.4 \pm 7.71$ in CAS1, $70.4 \pm 8.43$ in CAS2, 68.7 \pm 6.01 in CAS3 and $66.9 \pm 6.32$ in CAS4.

Variation in EL was not much prominent among four sub-lineages of $M . m$. castaneus. It was measured as $13.2 \pm 1.76,12.9 \pm 1.43$, $13.3 \pm 1.42$ and $13.7 \pm 2.04$ from CAS 1 to CAS 4, respectively. Unlike other characters mentioned above, HFL was smallest in CAS $2(15.8 \pm 2.32)$ and largest in CAS3

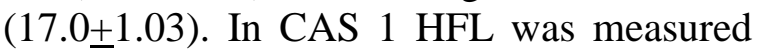
$16.7 \pm 0.16$ and in CAS 4 it was $16.5 \pm 1.74$. Discriminant function analysis (DFA) based on five morphological measurements was $46.7 \%$ accurate in assigning the individual specimens to the correct sub-lineage identified on the basis of molecular analysis (Table 2). From the values of standardized canonical discriminant coefficients in (Table 3) it can be concluded that HFL, BW and HBL are the variables which are playing important role in discrimination between CAS sub-lineages as larger the standardized coefficient, greater is the contribution of the respective variable to the discrimination between groups. Position of group centroids in canonical discriminant functions graph (Fig. 3) also shows that morphological differentiation between the sub-lineages is not complete as clusters for all sub-lineages overlap to varying degree.

Results of DFA show that classification of specimens into respective sub-lineage on the basis of cranial characters was $69.6 \%$ correct (Table 4) and according to standardized canonical discriminant function coefficients IFL and GSL were the most important skull characters for classification into respective group (Table 5). Position of group centroids in canonical discriminant functions graph (Fig. 4) for skull variables shows that there was considerable differentiation between the sub-lineages as 
there was less overlap between clusters for each sub-lineage and group centroids were also separated considerably.

Tremendous variation was observed in the dorsal and ventral coat colour of castaneus which varied from light orange brown and dark golden brown to dark grey dorsally and light orange/peach and fawn colour to pure white ventrally. There was also variation in foot colour from light pinkish brown to pure white and to black. A discriminant function analysis based on dorsal and ventral coat colour variables (taken together) was $47.1 \%$ accurate in assigning the individual specimens to the correct sub-lineage identified on the basis of molecular analysis (Table 6). Values of standardized canonical discriminant coefficients for these variables are given in (Table 7) which shows that ventral coat colour plays important role in discrimination between CAS sub-lineages. Position of group centroids in canonical discriminant functions graph (Fig. 5) also shows that differentiation between the sublineages is not complete as clusters for all sub-lineages overlap to varying degree.

Table 2. Percentage count of the number of specimens correctly classified to the respective sub-lineage on the basis of Discriminant Function Analysis (DFA) of External Morphological Variables

\begin{tabular}{|c|c|c|c|c|c|c|}
\hline \multirow{6}{*}{$\%$ Count } & \multirow{2}{*}{ Sub-lineage } & \multicolumn{4}{|c|}{ Predicted Group Membership } & \multirow{2}{*}{ Total } \\
\hline & & C1 & $\mathrm{C2}$ & C3 & $\mathrm{C4}$ & \\
\hline & $\mathrm{C} 1$ & 41.7 & 20.8 & 25.0 & 12.5 & 100.0 \\
\hline & $\mathrm{C} 2$ & 0.0 & 74.1 & 12.1 & 13.8 & 100.0 \\
\hline & $\mathrm{C} 3$ & 15.6 & 12.5 & 56.3 & 15.6 & 100.0 \\
\hline & $\mathrm{C} 4$ & 8.3 & 33.3 & 8.3 & 50.0 & 100.0 \\
\hline
\end{tabular}

$46.7 \%$ of original grouped cases correctly classified

Table 3. Standardized Canonical Discriminant Function Coefficients of morphological variables for $M$. $m$. castaneus sub-lineages. CAS-1 $(\mathrm{N}=22)$, CAS-2 $(\mathrm{N}=56), \mathrm{CAS3}-(\mathrm{N}=31)$ and CAS-4 $(\mathrm{N}=31)$

\begin{tabular}{|c|c|}
\hline Variable & Function 1 \\
\hline BW & .485 \\
\hline HBL & .301 \\
\hline TL & .296 \\
\hline EL & -.165 \\
\hline HFL & -.664 \\
\hline
\end{tabular}

Table 4. Percentage count of the number of specimens correctly classified to the respective sub-lineage on the basis of Discriminant Function Analysis (DFA) of cranial variables

\begin{tabular}{|c|c|c|c|c|c|c|}
\hline \multirow{4}{*}{\begin{tabular}{c}
$*$ \\
\multirow{4}{*}{ Sub-lineage }
\end{tabular}} & \multicolumn{4}{|c|}{ Predicted Group Membership } & \multirow{2}{*}{ Total } \\
\cline { 2 - 7 } & & C1 & C2 & C3 & C4 & \\
\cline { 2 - 7 } & $\mathrm{C} 1$ & 75.0 & .0 & 25.0 & 0.0 & 100.0 \\
\cline { 2 - 7 } & $\mathrm{C} 2$ & 7.7 & 61.5 & 7.7 & 23.1 & 100.0 \\
\cline { 2 - 7 } & $\mathrm{C} 3$ & 0.0 & 0.0 & 75.0 & 25.0 & 100.0 \\
\cline { 2 - 7 } & $\mathrm{C} 4$ & 7.7 & 15.4 & 7.7 & 69.2 & 100.0 \\
\hline
\end{tabular}

$69.6 \%$ of original grouped cases correctly classified 
Table 5. Standardized Canonical Discriminant Function Coefficients of cranial variables for M. m. castaneus sub-lineages. CAS-1 $(\mathrm{N}=22), \mathrm{CAS}-2(\mathrm{~N}=56)$, CAS3- $(\mathrm{N}=31)$ and CAS-4 $(\mathbf{N}=\mathbf{3 1})$

\begin{tabular}{|c|c|}
\hline Variable & Function 1 \\
\hline GSL & -.652 \\
\hline NL & -.249 \\
\hline CB & .181 \\
\hline CD & .420 \\
\hline ZB & -.279 \\
\hline BFM & .349 \\
\hline IFL & .774 \\
\hline
\end{tabular}

Table 6. Percentage count of the number of specimens correctly classified to the respective sub-lineage on the basis of Discriminant Function Analysis (DFA) of coat colour variables

\begin{tabular}{|c|c|c|c|c|c|c|}
\hline \multirow{4}{*}{$\begin{array}{c}\text { Sub- } \\
\text { \% }\end{array}$} & \multicolumn{3}{|c|}{ Predicted Group Membership } & \multirow{2}{*}{ Total } \\
\cline { 2 - 7 } Count & $\mathrm{C} 1$ & 44.7 & 29.4 & 25.9 & 0.0 & 100.0 \\
\cline { 2 - 7 } & $\mathrm{C} 2$ & 4.2 & 85.4 & .0 & 10.4 & 100.0 \\
\cline { 2 - 7 } & $\mathrm{C} 3$ & 7.1 & 3.6 & 71.4 & 17.9 & 100.0 \\
\cline { 2 - 7 } & $\mathrm{C} 4$ & 0.0 & 64.3 & 0.0 & 35.7 & 100.0 \\
\hline
\end{tabular}

$47.1 \%$ of original grouped cases correctly classified

Table 7. Standardized Canonical Discriminant Function Coefficients of coat colour variables for $M$. $m$. castaneus sub-lineages. CAS-1 ( $=22)$, CAS-2 $(\mathrm{N}=56)$, CAS3- $(\mathrm{N}=31)$ and CAS-4 $(\mathrm{N}=31)$

\begin{tabular}{|c|c|}
\hline Variable & Function 1 \\
\hline$(\mathrm{D}) \mathrm{V}$ & -.152 \\
\hline$(\mathrm{D}) \mathrm{C}$ & -.327 \\
\hline $\mathrm{D}(\mathrm{Hue})$ & .110 \\
\hline$(\mathrm{V}) \mathrm{V}$ & .429 \\
\hline$(\mathrm{V}) \mathrm{C}$ & .537 \\
\hline$(\mathrm{V}) \mathrm{HUE}$ & .304 \\
\hline
\end{tabular}




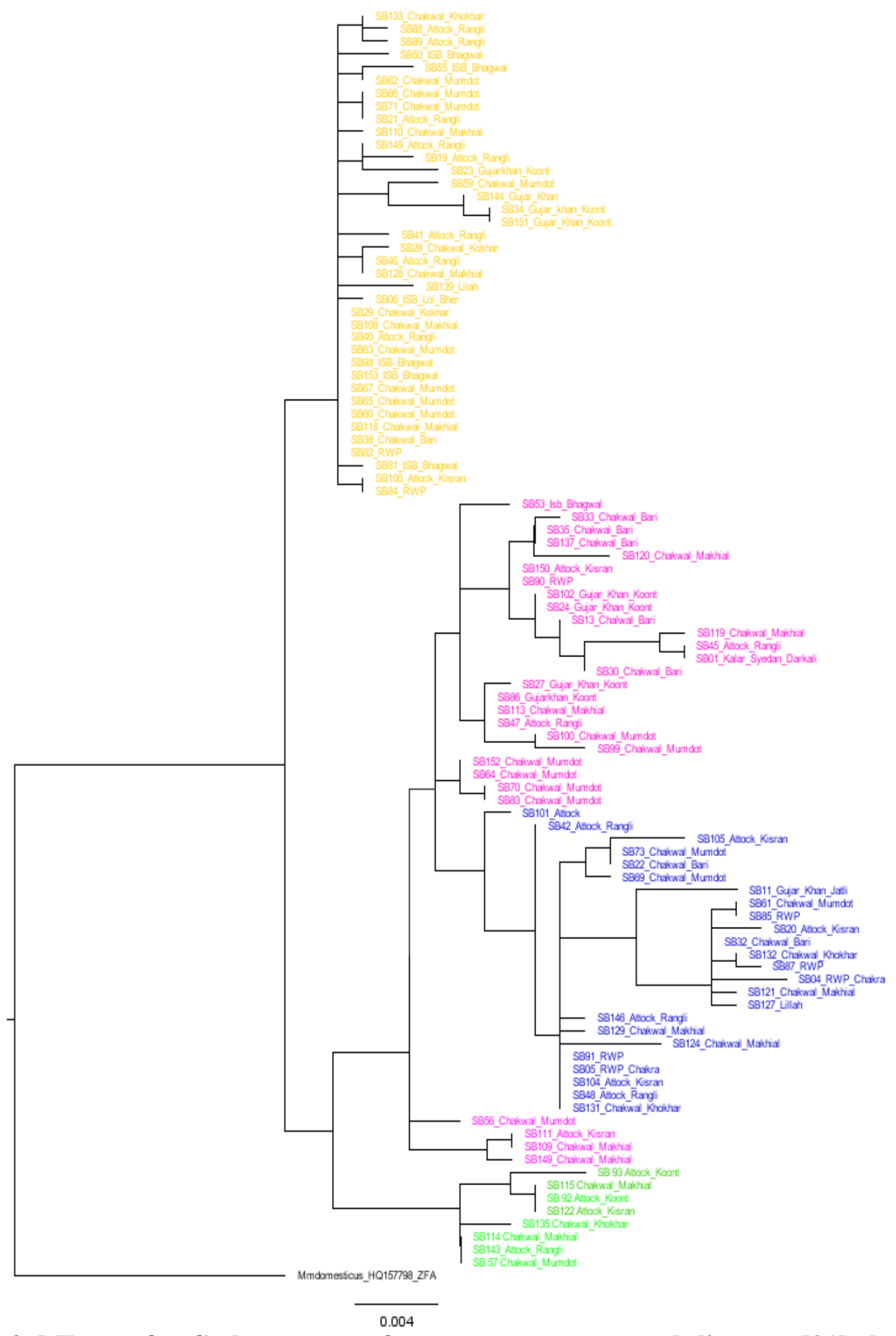

Figure 2. ML tree for Cytb sequences from $M$. m. castaneus sub-lineages [31] along with $M$. m. domesticus used as out group. (Green CAS1, yellow CAS2, blue CAS3, pink CAS4) 
Bibi et al.

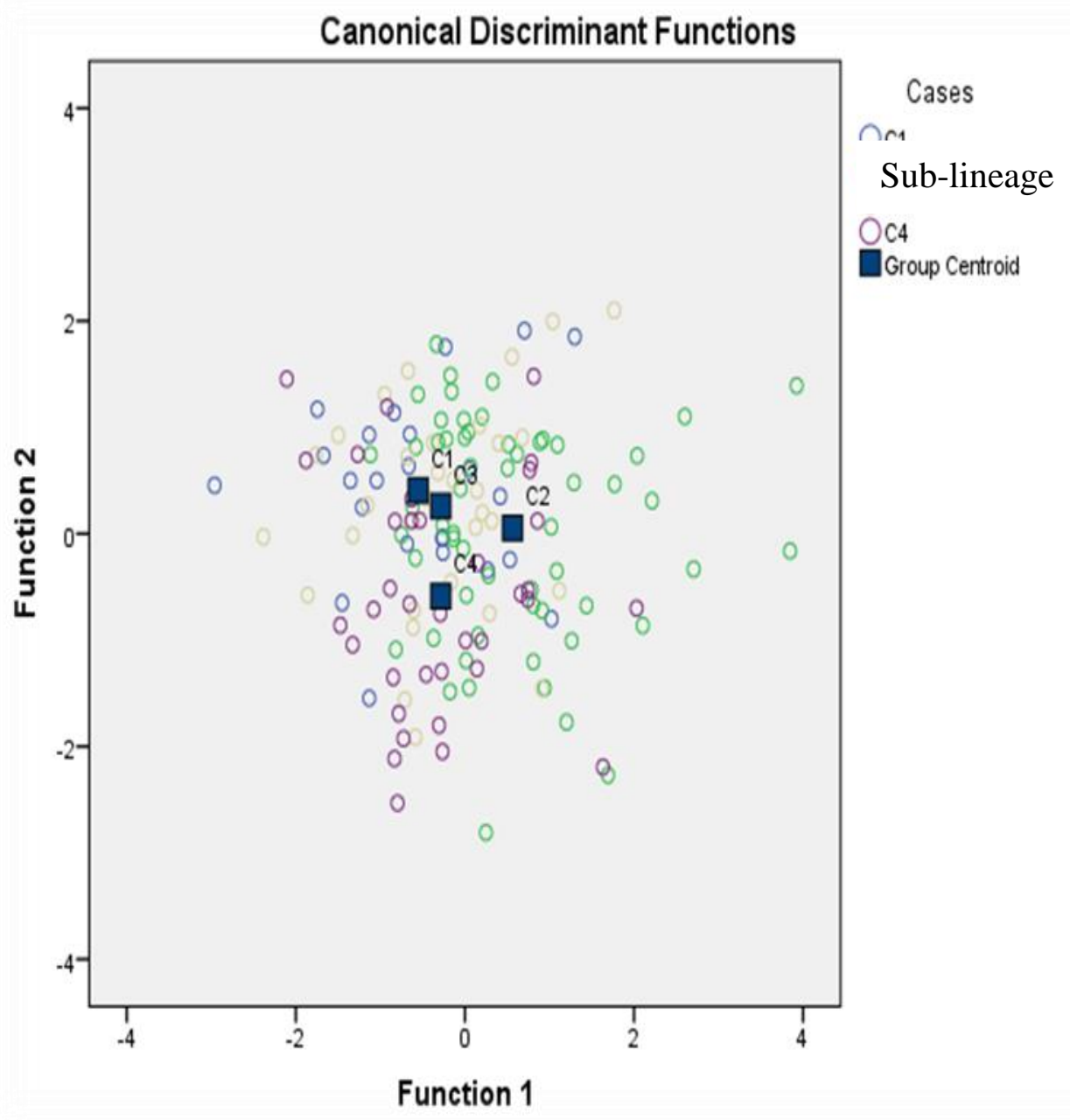

Figure 3. Discriminant Function Analysis ( $1^{\text {st }}$ two functions) of 5 morphological variables. Overlapping of the clusters for different sub-lineages indicate that sub-lineages are not completely distinguishable on the basis of morphological characters. CAS-1 $(\mathrm{N}=22)$, CAS$2(\mathrm{~N}=56)$, CAS3- $(\mathrm{N}=31)$ and CAS-4 $(\mathrm{N}=31)$ 


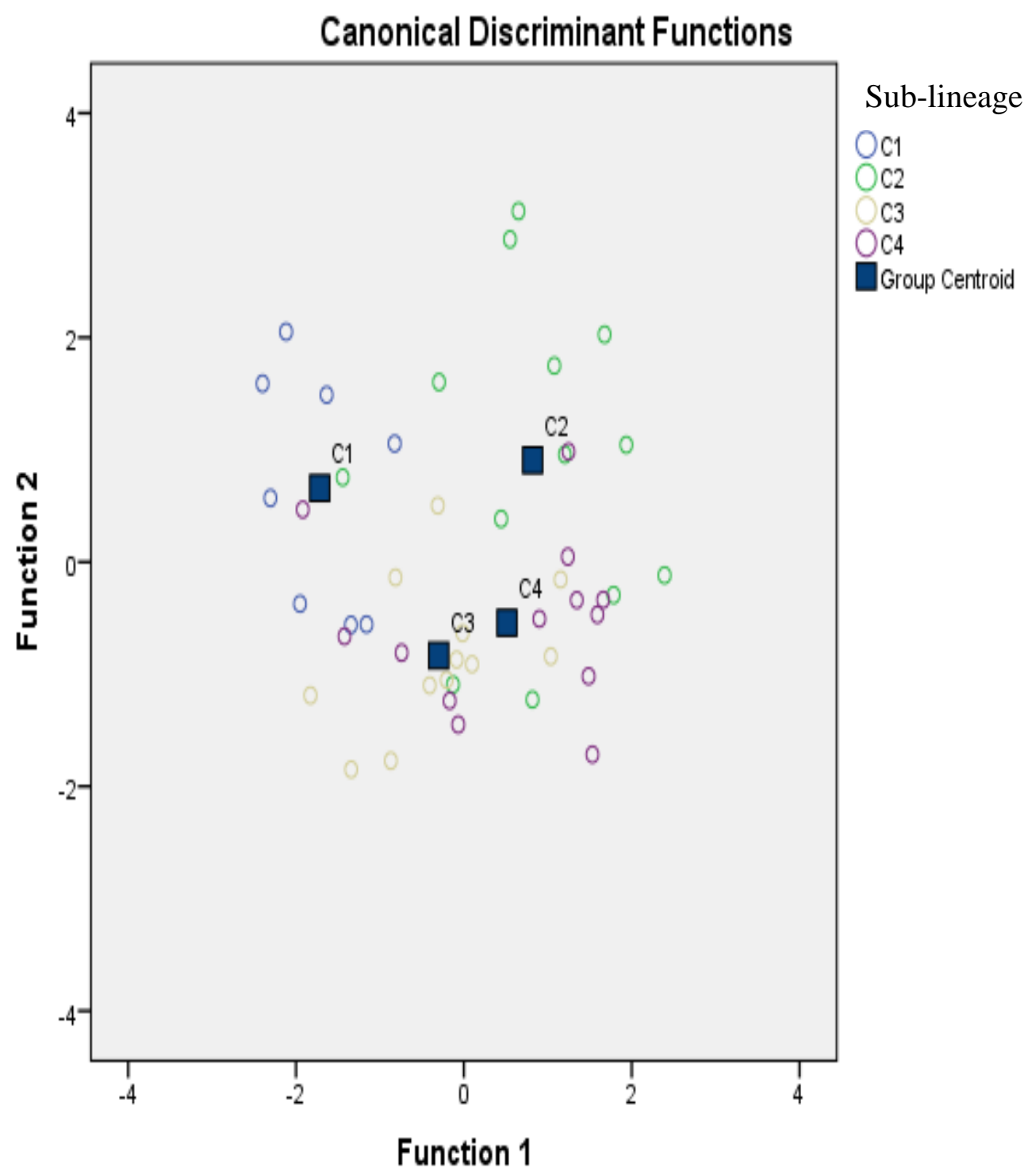

Figure 4. Discriminant Function Analysis ( $1^{\text {st }}$ two functions) of cranial variables. Less overlapping of the clusters for different sub-lineages indicates that sub-lineages are considerably distinguishable on the basis of cranial characters. CAS-1 $(\mathrm{N}=22), \mathrm{CAS}-2$ $(\mathrm{N}=56)$, CAS3- $(\mathrm{N}=31)$ and CAS-4 $(\mathrm{N}=31)$ 


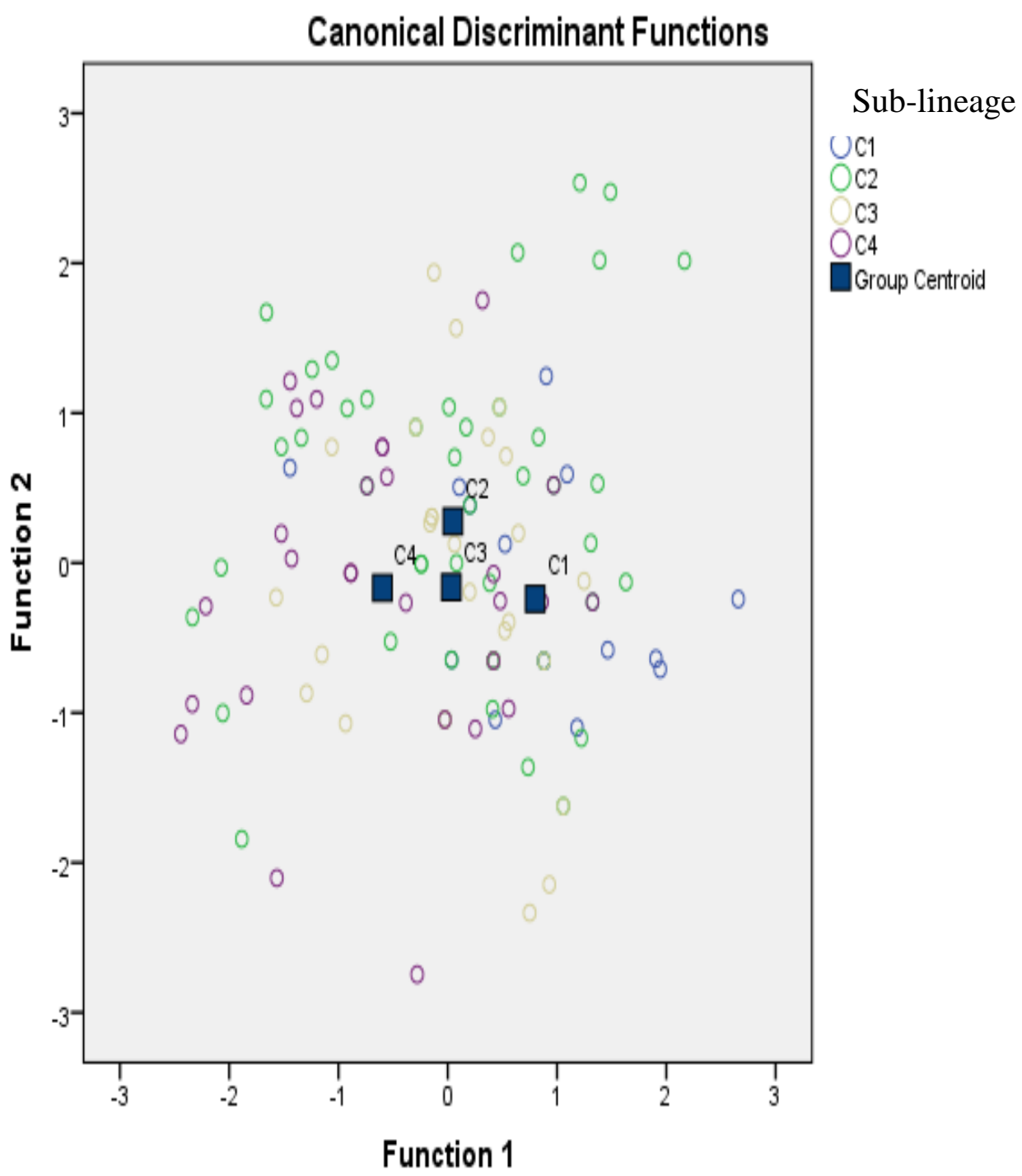

Figure 5. Discriminant Function Analysis ( $1^{\text {st }}$ two functions) of coat colour variables. Overlapping of the clusters for different sub-lineages indicate that sub-lineages are not completely distinguishable on the basis of coat colour characters. CAS-1 $(\mathrm{N}=22)$, CAS-2 $(\mathrm{N}=56)$, CAS3- $(\mathrm{N}=31)$ and CAS-4 $(\mathrm{N}=31)$

\section{Discussion}

Analysis of genetic and morphological diversity by present study provided valuable knowledge about the mice populations of northern Pakistan. Principal findings of this study is that $M$. m. castaneus populations of this region have substantial morphological variation depicted by more than one Cytb sub-lineages which may coexist and are distributed throughout Pothwar region and may not show geographical segregation. In this way this study explores the diversity and "polytypic character" of $M . \quad m$. castaneus i.e. it is represented by more than one genetic entity and morphological forms. This view has been strengthened by tremendous coat colour variation found in this sub-species. 
As the basic structure and transformation of the morphological character has the genetic basis, there has been a growing trend of analyzing the morphological species by genetics and molecular markers [11-17]. Biosystematics studies the taxonomical status and evolution of taxa based upon statistical data, determines how a species differentiates into sub-species through time and space under the effect of genetic information [18]. Although in recent years there has been tremendous increase in the use of molecular techniques in the field of phylogenetics, however study of morphological characters still remains an important tool in inferring phylogenies [1924] as morphological data can be collected more easily from large number of preserved museum specimens and also from fossil record [25]. Moreover, morphometric data can also be used to study the selection pressures and trends for adaptations within a taxa or lineage [26-29].

In present study, morphological analysis of all body measurements for three sub-species including external body characters and skull variables were in good agreement with previous reports [8] except very clear disagreement in the case of tail length for $M$. $m$. castaneus. According to previous reports M. m. castaneus has been characterized by tail length longer than body length [8] but according to present study tail length was never longer than body length rather specimens from Pothwar populations of $M$. $m$. castaneus always have tail length equal or shorter than body length. This disagreement about the $M$. $m$. castaneus populations of Pothwar can be attributed to the absence of data specific to $M . m$. castaneus populations of Pakistan as $M . m$. castaneus populations in Pakistan have never been the subject of any comprehensive study characterizing this population genetically and morphologically.

Visibly shorter tail and comparatively larger skull in $M . m$. castaneus from Pothwar can also be attributed to the life history and adaptations according to the habitat as study of morphometric variations among commensal and non-commensal mice populations belonging to same species $(M$. musculus) by [30] explained the effect of life history and ecology on the morphological characters and according to them populations exhibiting commensal mode of life had smaller skulls and much longer tails than non-commensal populations of the same sub-species. Shorter tail length is an ancestral character in M. musculus as it is proved by the fact that other close relatives of $M$. musculus (M. spicilegius, $M$. macedonicus and $M$. spretus) have shorter tail length. So, the longer tail length is an adaptation to commensal mode of life as tail movements contributes to the better survival in three dimensional commensal habitats [30].

Craniometric data revealed that $M . m$. castaneus populations of study area are characterized by broader zygomatic plate and a clearly notched tip of the upper incisor as observed in 100\% captured samples. Considerable variations observed in $M . \mathrm{m}$. castaneus coat colour by present study are suggestive of either strong selection in the different habitats or partially segregated gene pools. Traditionally, M. m. castaneus has been reported as dark coloured mice while $M$. $m$. bactrianus is identified as having golden brown or bright yellow dorsal fur but in present study tremendous coat colour variation in castaneus was observed which approaches the description of bactrianus. So, this study supports the view discussed by some previous authors e.g. [6] that what had been called bactrianus now seems to be part of high mtDNA diversity that exists among castaneus populations from Pakistan and northwest India. So, coat colour variation within castaneus can be an interesting topic for future research in 
Pakistan.

\section{Conclusion}

This study provided validated information about the Mus fauna of Pothwar region, and led to the conclusion that more than one clades of South East Asian subspecies M. m. castaneus are intermingled in this area which were previously known to have a non-overlapping geographical distribution. This view has been strengthened by the tremendous coat colour variation found in this sub-species. This study supports the view held by some other authors that long debated $M$. m. bactrianus seems to be the part of high mtDNA diversity present among M. m. castaneus populations of Pakistan and northwest India. Capture of $M$. cookii specimen during this study may represent a case of previously unknown mice or it may provide a clue about major range expansion of this species which was previously never reported from Pakistan or from western parts of Asia and thus provides insight for future endeavors focusing on this subject.

\section{Authors' contributions}

Conceived and designed the experiments: MS Nadeem, Performed the experiments: $S$ Bibi, Analyzed the data: T Mahmood \& Franc Janzekovic, Contributed materials/ analysis/ tools: AR Kayani, Wrote the paper: S Bibi \& M Mushtaq.

\section{Acknowledgments}

This study was partially funded by Higher Education Commission of Pakistan (HEC).

\section{References}

1. Awasthi M, Bhat KV \& Anand RK. (1998). Genetic Heterogeneity in the Indian Mus musculus. Biochem Genet 36: 245-258.

2. Boursot P, Auffray JC, Davidian JB \& Bonhomme F (1993). The Evolution of House Mice. Ann Rev of Ecol and Systematic 24: 119-152.

3. Suzuki H, Nunome M, Kinoshital G, Aplin K, Vogel P, Kryukov A, Jin ML, Han SH, Maryanto I, Tsuchiya K, Ikeda H, Shiroishi T, Yonekawa H \& Moriwaki K (2013). Evolutionary and dispersal history of Eurasian house mice Mus musculus clarified by more extensive geographic sampling of mitochondrial DNA. Heredity 92: 1-16.

4. Phifer-Rixey M, Bonhomme F, Boursot P, Churchill GA, Piálek J, Tucker PK \& Nachman MW (2012). Adaptive evolution and effective population size in wild house mice. Mol Bio Evolu. online April 3, 2012 doi:10.1093/molbev/mss105.

5. Duvaux L, Belkhir K, Boulesteix M \& Boursot P (2011). Isolation and gene flow: inferring the speciation history of European house mice. Mol Ecol 20: 5248-5264.

6. Rajabi-Maham H, Orth A, Siahsarvie R, Boursot P, Darvish J \& Bonhomme F. (2012). The south-eastern house mouse Mus musculus castaneus (Rodentia: Muridae) is a polytypic subspecies. Bio J of Linnean Soc 107: 295-306.

7. Bibi S, Nadeem MS, Wiewel AA, Beg MA, Hamid K, Jabeen M \& Raja GK (2017). Mitochondrial Genetic Diversity and Phylogeography af Mus musculus castaneus in Northern Punjab, Pakistan. Zool Sci 34(6): 490-497.

8. Marshall JT (1977). A synopsis of Asian species of Mus (Rodentia, Muridae). Bull of Am Mus of Natu His 158: 174-220.

9. Musser GG \& Carleton MD (1993). Family Muridae. In: DE Wilson \& DM Reeder (eds.), Mammal species of the world. (Smithsonian Institution Press, Washington, DC. 501-755.

10. Lai YC, Shiroshi T, Moriwaki K, Motokawa M \& Yu HT (2008). Variation of coat color in house mice throughout Asia. J of Zool 274: 270-276.

11. Darviche J \& Orsini P (1982). Criteres differenciation morphologique et biometrique de deux esp` eces de souris sympatriques: Mus spretus et MM domesticus. Mammalia 46: 205-217.

12. Darvish J (1988). Discrimination of different subspecies of house mouse Mus musculus from Eurasia and North Africa on the basis of their morphometric characteristics. Iranian J of Biol 7: 49-71.

13. Darvish J (1997). Morphological studies of denttary and skull of house mouse $(M$. musculus L.) from Eurasia and North Africa. Iranian J of Biol 4(1): 84-110.

14. Darvish J (2004). Analysis of morphological 
variations of molars teeth of house mouse Mus musculus of Eastern Iranian and their relative oldness in comparison with Mediterranean basin house mouse. Iranian J of Biol 16: 13-19.

15. Boursot P, Din W, Anand RK, Darviche D, Dod B, Deimling FV, Talwar G \& Bonhomme F (1996). Origin and radiation of the house mouse: mitochondrial DNA phylogeny. J of Evolu Biol 9(4): 391-415.

16. Prager EM, Orrego C \& Sage DR (1998). Genetic Variation and phylogeography of Central Asian and Other House Mice, Including a Major New Mitochondrial Lineage in Yemen. Genetics 150:835-861.

17. Darvish J, Orth A \& Bonhomme F (2006). Genetic transition in the house mouse, Mus musculus of Eastern Iranian Plateau. Folia Zool 55(4): 349-357.

18. Darvish J (2008). Biosystematic approach to geographic variations of house mouse group, Mus musculus (L.1766). Iranian J of Ani Biosyst 4: 31-54.

19. David B \& Laurin B (1996). Morphometrics and cladistics: measuring phylogeny in the sea urchin Echinocardium. Evolution 50: 348-359.

20. Corti M, Aguilera M \& Capanna E (1998). Phylogeny, size and shape changes in the skull of the South American rodent Proechimys. Acta Zoologica Academiae Scientiarum Hungaricae 44: 139-150.

21. Steppan SJ (1998). Phylogenetic relationships and species limits within Phyllotis (Rodentia: Sigmodontinae. Concordance between mtDNA sequence and morphology. J of Mammal 79: 573-593.

22. Velzen VJ, Bouton N \& Zandee R (1998). A procedure to extract phylogenetic information from morphometric data. Netherland $\mathrm{J}$ of Zool 48: 305-322.

23. Mauk CL, Houck JB \& Bradley RD (1999). Morphometric analysis of seven species of pocket gophers (Geomys). J of Mammal 80: 499-511.

24. Simmons NB \& Conway TM (2001). Phylogenetic relationships of mormoopid bats (Chiroptera: Mormoopidae) based on morphological data. Bull of Am Mus of Natu His 258: 1-97.

25. Hillis DM (1987). Molecular versus morphological approaches to systematics. Ann Rev of Ecol and Syst 18: 23-42.

26. Long AD \& Singh RS (1995). Molecules versus morphology: the detection of selection acting on morphological characters along a cline in Drosophila melanogaster. Heredity 74: 569-581.

27. Corti M \& Fadda C (1996). Systematics of Arvicanthis (Rodentia, Muridae) from the Horn of Africa. A geometric morphometrics evaluation. Italian J of Zool 63(2): 185-192.

28. Corti M, Fadda C, Simson S \& Nevo E (1996). Size and shape variation in the mandible of the fossorial rodent Spalax ehrenbergi. A procrustes analysis in three dimensions. In: LF Marcus, M Corti, A Loy, GJP Naylor \& DE. Slice (eds.), Advances in Morphometrics. Plenum Press, New York. pp. 303-320.

29. Hansen TF (1997). Stabilizing selection and the comparative analysis of adaptation. Evolution 51: 1341-1351.

30. Sla'bova M \& Frynta D (2007). Morphometric variation in nearly unstudied populations of the most studied mammal: the non-commensal house mouse (Mus musculus domesticus) in the Near East and Northern Africa. Zoologischer Anzeiger 247: 91-101.

31. Bibi S (2015). Habitat Distribution, Diversity and Systematic of Mus spp in Pothwar, Pakistan. PMAS-Arid Agriculture University Rawalpindi. Doctoral dissertation. 